\title{
An Experimental Study of Biochemical and Histopathological Study on Gentamycin Induced Renal Failure in Albino Rat And The Effectiveness Of Punarnava (BOERHAEVIA Diffusa) On Reversal Of Renal Damage
}

\author{
M.Pramila Padmini ${ }^{1}$, J. Vijay Kumar ${ }^{2}$ \\ ${ }^{1}$ (Assistant Professor of Anatomy, MIMS Medical College Vizianagaram, Nellimarla, India) ${ }^{2}$ Professor of \\ Anatomy, Saveetha Medical College, Chennai, India)
}

\begin{abstract}
Drug-induced nephrotoxicity is an important cause of renal failure. Aminoglycosides throughout the endocytic pathway are taken up into the epithelial cells of the renal proximal tubules and stay there for a long time, which leads to nephrotoxicity. Wistar- albino male rats weighing 125-150gms, are utilized for the present study.Blood samples were collected with cardiac puncture for biochemical investigations like blood urea, uric acid, creatinine, serum Na, K, Ca, determination.By using one way ANOVA the results are significant at .001. Hyaline cast formation is observed in PCT with atrophic glomeruli effecting half of the cortical region when rats treated with $80 \mathrm{mg} / \mathrm{kg}$ b.w. administration of Punarnava $400 \mathrm{mg}$ and $800 \mathrm{mg} / \mathrm{kg} . \mathrm{bw}$ rejuvenated necrotic cells of kidney. Gentamicin must be given in the lowest effective therapeutic doses in patients with normal kidney function along with punarnava.
\end{abstract}

Key words: gentamycin, glomeruli, lymphatic infiltration, proximal convoluted tubules, punarnava

\section{Introduction}

Drug-induced nephrotoxicity is an important cause of renal failure. Aminoglycosides throughout the endocytic pathway are taken up into the epithelial cells of the renal proximal tubules and stay there for a long time, which leads to nephrotoxicity. Hydroxyl radicals play a role in the pathogenesis of gentamicin nephrotoxicity, gentamicin can induce suppression of $\mathrm{Na}(+)-\mathrm{K}(+)$-ATPase activity and DNA synthesis in rats proximal tubules leading to renal injury; this injury may be relevant to reactive oxygen metabolites generated by gentamicin. Renal cortical mitochondria is the source of reactive oxygen metabolites, which induces renal injury ( Nephrol Dial Transplant. 1994;9 Suppl 4:135-40[1]).

Pharmacological studies have demonstrated that $B$. diffusa exhibits a wide range of properties such as diuretic [Gaitonde BB, et al 1974[2]; nephrotic syndrome [Singh RH et al 1972[3]; antiurolithiatic [Pareta SK et al 2011[4]; antioxidant and antidiabetic activity . Due to the combination of diuretic, antioxidants and antiinflammatory activities B. diffusa is regarded as therapeutically highly efficacious for the treatment of inflammatory renal diseases and common clinical problems such as nephrotic syndrome, oedema, and ascites. Boerhavia Diffusa has been reported to be useful in the treatment of elephantiasis, night blindness, corneal ulcers and nephritic syndrome(Mishra J, et al 1980[5], Singh RH, et al 1972[3]).

The protection offered by the B.diffusa aqueous extract could have been due to the presence of any of the active principles contained in it. Literature has shown B. diffusa contains a large number of compounds such as flavonoids, alkaloids, steroids, triterpenoids, lipids, lignins, carbohydrates, proteins, and glycoproteins . Flavonoids and other antioxidant constituent of medicinal plants have been reported to inhibit xenobiotic induced nephrotoxicity in experimental animal models due to their potent anti-oxidant effects [Devipriya $\mathrm{S}$ et al 1999[6]. Very few studies of histopathology were reported in literature with the effectiveness of punarnava (Boerhaevia diffusa) on gentamicin induced renal failure in Albino rats and to estimate the damage and revival of renal tissue. So, the present study is taken up to record the anti-nephrotoxic effects of punarnava.

\section{Materials And Methods}

Wistar - albino male rats weighing $125-150 \mathrm{~g}$, are utilized for the present study. Experiments were performed with the permission of the institutional ethics committee.

In the present study, male albino rats were used and are grouped as follows:

* group I- 6 albino rats with normal saline for 10 days and are sacrificed on the $11^{\text {th }}$ day.

*(group-II- 6 albino rats with $400 \mathrm{mg} / \mathrm{kg}$. b.wt of punarnava(pure extract obtained in capsules from himalaya product-each capsules containing $250 \mathrm{mg}$ of extract of pure punarnava powder). for 10 days and are sacrificed on the $11^{\text {th }}$ day. 
*group-III-10 albinorats with $80 \mathrm{mg} / \mathrm{kg}$. b.wt of gentamycin for 10 days. On $11^{\text {th }}$ day 6 animals are sacrificed and remaining 4 are left without giving any treatment to see whether there is self regeneration.

*group-IV-10 albino rats with $80 \mathrm{mg} / \mathrm{kg}$. b.wt of gentamycin for 10 days and from 11 th day treated with punarnava $400 \mathrm{mg} / \mathrm{kg}$. b.wt for 3 weeks by the end of third wk two rats were sacrificed to see the regenerative changes. By the end of six weeks another two rats were sacrificed to see the changes.by the end of 9 wks all the 6 rats were sacrificed to see the changes.

*group-V- 10 albino rats with $80 \mathrm{mg} / \mathrm{kg}$. b.wt of gentamycin for 10 days and from 11 th day treated with with punarnava $800 \mathrm{mg} / \mathrm{kg}$. b.wt for 3 weeks by the end of $3^{\text {rd }}$ wk two rats were sacrificed to see the regenerative changes. by the end of 6 wks another two rats were sacrificed to see the changes. By the end of 9 wks all the 6 rats were sacrificed to see the changes.

- All animals were fed standard rat chow and were provided tap water to drink ad libitum. All animals were weighed before the injections. The animals were anaesthetized with ether inhalation.

- Blood samples were collected from retro-orbital plexus for biochemical investigations like blood urea, uric acid, creatinine, serum $\mathrm{Na}, \mathrm{K}, \mathrm{Ca}$, determination. Bilateral periumbilical vertical incisions were made. Right and left kidneys were removed quickly and weighed and preserved in $10 \%$ formalin.

\section{- Histopathological examination:}

Anterior half of Kidneys from all three groups were fixed in $10 \%$ neutral buffered formalin and processed to paraffin wax. 5 microns Sections are stained with Haematoxylin and Eosin, Massons trichrome, and Periodic Acid Schiff and are examined under light microscope at 100 and 400 magnification.

\section{Results}

Table (1): Comparative Nephrotoxic effects of gentamicin and nephroprotective effects of different doses of Boerhavia diffusa (Punarnava) on some biochemical parameters in rats.

\begin{tabular}{|c|c|c|c|c|c|}
\hline & $\begin{array}{c}\text { Group-I } \\
\text { CONTROL- } \\
\text { SALINE }\end{array}$ & $\begin{array}{l}\text { Group-II } 400 \mathrm{mg} \\
\text { B.diff/kg.b.w }\end{array}$ & $\begin{array}{c}\text { Group-III } \\
\text { 80mg gen./kg.b.w }\end{array}$ & $\begin{array}{l}\text { Group-IV } 80 \mathrm{mg} \\
\text { gen./kg.b.w for } \\
\text { 10days and } \\
400 \mathrm{mg} / \mathrm{kg} . \mathrm{b} . \mathrm{wt} \\
\text { punarnava from } \\
11 \text { th day for } 9 \\
\text { weeks }\end{array}$ & $\begin{array}{l}\text { Group-V } \\
80 \mathrm{mg} \text { gen. } / \mathrm{kg} . \mathrm{b} . \mathrm{w} \\
\text { for } 10 \text { days and } \\
800 \mathrm{mg} / \mathrm{kg} . \mathrm{b} . \mathrm{wt} \\
\text { punarnava from } \\
11 \text { th day for } 9 \\
\text { weeks }\end{array}$ \\
\hline PARAMETERS & $\mathrm{MEAN+SD}$ & MEAN+SD & $\mathrm{MEAN}+\mathrm{SD}$ & MEAN+SD & MEAN+SD \\
\hline žUrea $(\mathrm{mg} / \mathrm{dl})$ & $16.8+0.43$ & $16.76+0.45$ & $74.3+1.46$ & $38.23+4.45$ & $22.16+2.15$ \\
\hline žCreatinine $(\mathrm{mg} / \mathrm{dl})$ & $0.46+0.02$ & $0.46+0.29$ & $2.14+0.21$ & $1.21+0.23$ & $0.67+0.07$ \\
\hline žUric acid $(\mathrm{mg} / \mathrm{dl})$ & $0.36+0.05$ & $0.37+0.04$ & $1.05+0.11$ & $0.68+0.07$ & $0.51+0.03$ \\
\hline ŽNa $($ meq/L) & $125.53+1.44$ & $124.62+2.26$ & $117.97+1.93$ & $119.6+1.56$ & $121.9+1.72$ \\
\hline žK $(\mathrm{meq} / \mathrm{L})$ & $4.06+0.08$ & $4.11+0.11$ & $5.58+0.43$ & $5.06+0.21$ & $4.5+0.22$ \\
\hline $\begin{array}{l}\text { žTotal calcium } \\
(\mathrm{mg} / \mathrm{dl})\end{array}$ & $9.21+0.45$ & $9+0.25$ & $7.7+0.50$ & $8.07+0.26$ & $8.66+0.46$ \\
\hline
\end{tabular}

Mean, Standard deviation and one way ANOVA was done to know the significance. All The Values Are Significant Between And Within Groups At .001

(- Values are expressed as means \pm S.D. By using one way ANOVA the results are significant .

Group-III -1 rat out of 4 rats which are not treated after inducing gentamycin toxicity for 10 days, died on the fourth day and remaining 3 rats were sacrificed on the eight day. Mean and S.D are similar to that of group-III and are excluded from the table.

\subsection{Histopathological Observations}

\subsubsection{Group-I -6 rats treated with normal saline $(0.9 \%$ Nacl $)$}

Male albino rats with intake of normal saline showed normal architecture of renal glomeruli with intact bowmans capsule. Brush bordered cuboidal epithelium lining the proximal convoluted tubules. Simple cuboidal epithelium lining the distal convoluted tubules .Macula densa is very prominent(fig.1).

\subsubsection{Group-II- rats treated with punarnava $400 \mathrm{mg} / \mathrm{kg}$ b.w}

The cytoarchitecture of kidneys showed normal structure of glomeruli, distinct proximal and distal convoluted tubules(fig.2). 


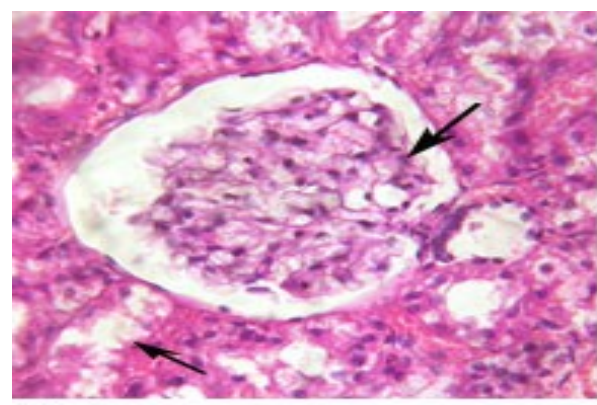

fig.1

fig.1 showing normal glomeruli and PCT with brush borded cuboidal epthelium in G-I rats

fig.2 showing normal glomeruli and continuous Boowman's capsule in G-II rats

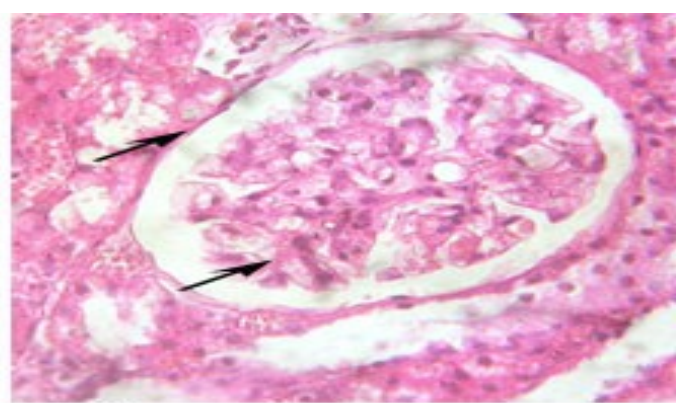

fig.2

3.1.3 Group-III -rats induced with gentamycin $80 \mathrm{mg} / \mathrm{kg}$ b.w

The use of the periodic acid-Schiff reaction confirmed that these apoptotic cells were almost exclusively found in proximal tubules causing obstruction of PCT'S. Tubular basement membrane is interrupted. Glomerular congestion, disruption of glomerular capillaries,vacuolar degeneration of tubular epithelial cells is observed with hyaline cast formation is observed in PCT. Atrophic glomeruli are present effecting half of the cortical region(fig.3). Lymphocytic infiltration has increased(fig.4) . Rats induced with gentamycin $80 \mathrm{mg} / \mathrm{kg}$ b.w for 10 days and not treated showed atrophic glomeruli and hyaline casts in PCT'S. There is no self regeneration.

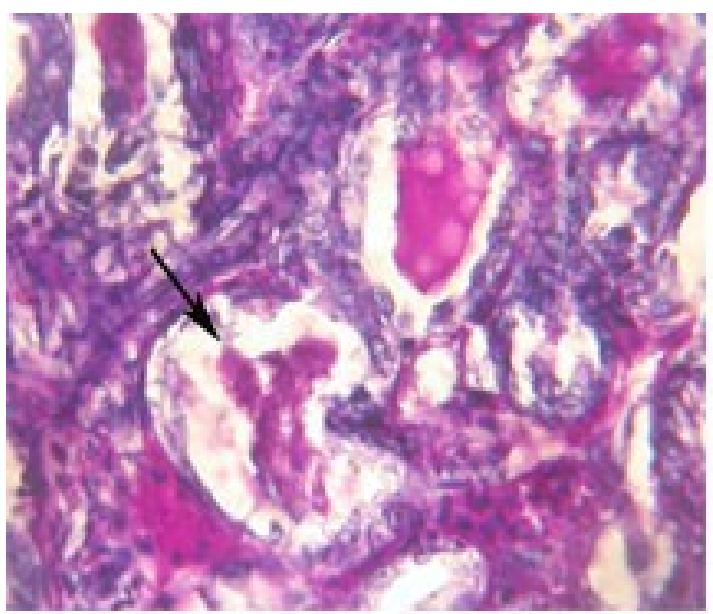

fig.3

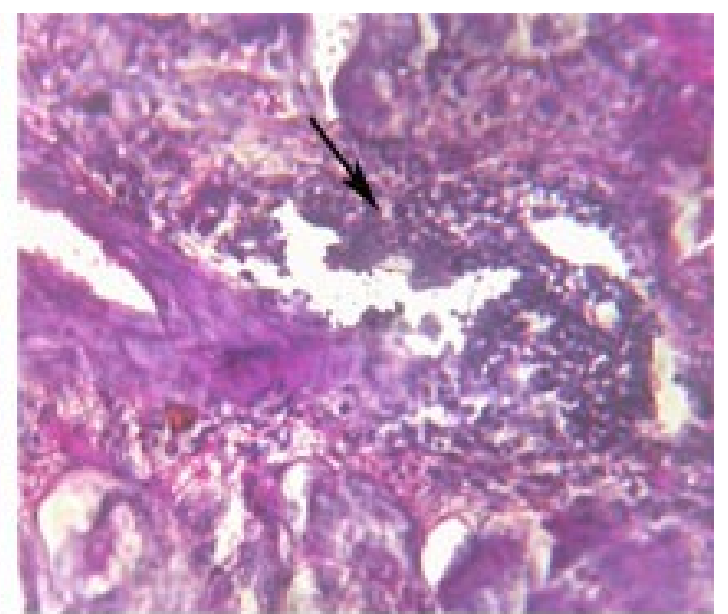

fig.4

\section{fig.3 showing atrophic glomeruli effecting half of the cortical} region in G-III rats, 10x40, PAS. fig.4 showing peritubular lymphocytic infiltration in G-III rats in G-III rats, 10x40, PAS.

\subsubsection{Group-IV- rats induced with $80 \mathrm{mg} / \mathrm{kg} . b w$ gentamycin and treated with $400 \mathrm{mg} / \mathrm{kg} . b w$ of punarnava}

After 3 wks of treatment, the renal microscopic details did not show any regeneration in kidneys of two rats. By the end of $6 \mathrm{wks}$, the PCT'S are lined with cuboidal epithelium and are clear without any hyaline cast(fig.5) and regeneration of luminal epithelium. By the end of 9 wks, the renal architecture showed $50 \%$ improvement in regeneration of glomerular tuft and distinct epithelium formation of proximal convoluted tubules(fig.6). 


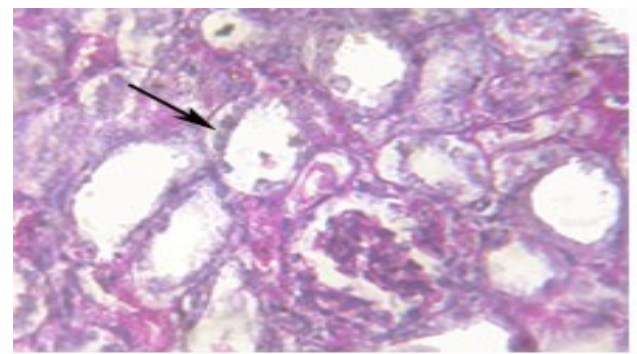

fig. 5

fig.5 showing PC'T'S without any hyal ular tuft, 10X10, H\&E

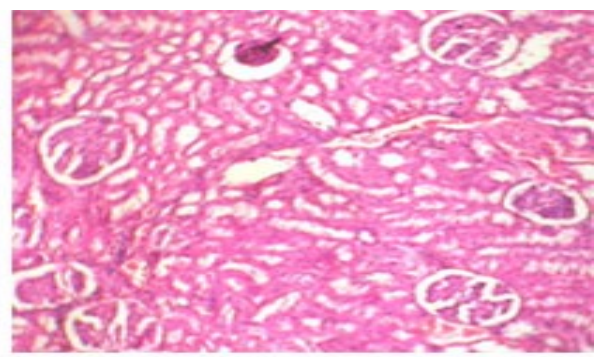

fig.6

mprovement in regeneration of glomer-

\subsubsection{Group-V- rats induced with $80 \mathrm{mg} / \mathrm{kg} . \mathrm{bw}$ gentamycin and treated with $800 \mathrm{mg} / \mathrm{kg}$.bw of punarnava}

By the end of $3 \mathrm{wks}$ the lymphatic infiltration in the proximal convoluted tubules disappeared indicating anti-nephrotoxic effect of punarnava. By the end of $6 \mathrm{wks}$, hyaline cast disappeared and by the end of $9 \mathrm{wks}$, $80 \%$ of glomeruli have regained their normal structureand enclosed ny continuous bowman's capsule(fig.7) showing continuity in the Bowman's membrane(fig.8).

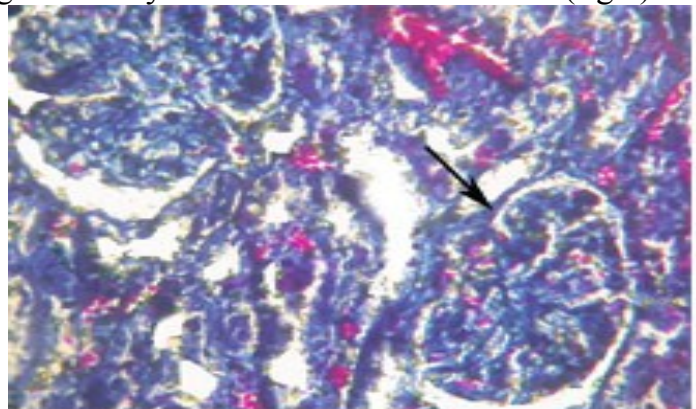

fig.7

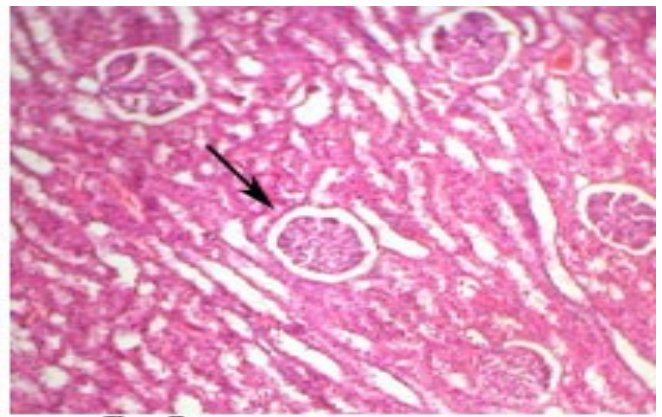

fig.8

fig.7 showing glomeruli having normal structure, 10x40, Massons Trichrome fig.8 showing continuity in the Bowman's membrane, $10 x 10$, H\&E.

\section{Discussion}

Acute renal failure is characterized by disorders in some biochemical parameters in gentamicin treated rats .Rats treated with $80 \mathrm{mg} / \mathrm{kg}$ b.w. Gentamicin produced increase in the concentration of serum urea, creatinine and uric acid.These results confirmed that gentamicin produced nephrotoxicity as previously reported by Ali et al., 2003[7], Goto, 2004[8] and Heibashy et al.,2009[9]. More than half of proximal tubules showing desquamation of necrosis but involved tubules easily found, complete or almost complete tubular necrosis. Serum electrolytes were disturbed in GM treated rats as compared with control animals. Lower value of serum sodium indicated inability of kidney to conserve sodium and chloride(Heibashy \& Abdel Moneim (1999)[10] and Heibashy et al. (2009[9]). Gentamicin treated rats show tubular eptithelial damage with intense granular degeneration involving $>50 \%$ of renal cortex. Some of the tubular epithelium contains tubular casts as observed by K.VIJAY KUMAR et al 2000[11]) . Gentamicin renal cell damage as induced by tubular necrosis ie, marked congestion of the glomeruli with glomerular atrophy, degeneration of tubular epithelial cells with casts in the tubular lumen and infiltration of inflammatory cells in the interstitium was confirmed on histopathological examination by Shirwaikar A et al 2003[12]. In the present study shrunken glomeruli and glomerular atrophy is observed by gentamycin induced renal damage $(80 \mathrm{mg} / \mathrm{k} . \mathrm{g}$. b.wt for 10 days) are in harmony with the above authors.

Surendra K 2011[13] investigated the effects of pre-treatment of aqueous extract of $B$. diffusa root (200 $-400 \mathrm{mg} / \mathrm{kg} / \mathrm{day})$ in repeated dose acetaminophen nephrotoxic rats for 14 days. pre-treatment with $B$. diffusa extract protected against degenerative changes renal cortical architecture in the experimental rats. Antioxidant enzymes such as Glutathioneperoxidase, Reduced glutathione, Vitamin C and Catalase were elevated in animals treated with Boerhaavia diffusa aqueous extract which showed that the aqueous extract of Boerhaavia diffusa leaves significantly reduced the nephrotoxicity induced by mercuric chloride(T.Indhumathi et al 2011[14]). The herb is a diuretic that acts on the glomeruli of the kidney and also protects the kidney from being damaged (Rawat et al, 1997[15]). 
Post -treatment with B. diffusa pure extract $(400 \mathrm{mg} / \mathrm{kg}$.b.wt and $800 \mathrm{mg} / \mathrm{kg} . b \mathrm{wt}$ for 9 wks exhibited antinephrotoxic effects(curative) against degenerative changes of renal cortical architecture and also significant normal values of biochemical parameters.

\section{Conclusion}

( ) Daily intraperitonial injection of rats with $80 \mathrm{mg}$ gentamicin $/ \mathrm{kg}$ b.w for 10 days caused a serious harmful effects on renal function tests.

○ Treatment with $B$. diffusa pure extract $(400 \mathrm{mg} / \mathrm{kg}$.b.wt and $800 \mathrm{mg} / \mathrm{kg} . b w t$ for 9 wks exhibited antinephrotoxic effects(curative). Histopathological findings indicate rejuvination of necrotic cell in kidney

- Thus, it could be suggested that gentamicin must be given in the lowest effective therapeutic doses in patients with normal kidney function.

- Also, gentamicin therapy should be accompanied with administration of punarnava which will nullify the nephrotoxic effect of gentamycin.

○ Boerhavia diffusa (Punarnava) even though given in larger doses will not have any side effects .

\section{Acknowledgements}

I thank Dr.B.Narasinga Rao, Professor and HOD of Anatomy, Dr.T.A.V.Narayana Raju Dean, Dr. Ramalakshmi, Professor and HOD of pathology and Dr.Mamatha bandopadhyay, Professor and HOD of Pharmacology of Maharajahs Institute Of Medical Sciences and Dr. Saraswathi Professor and HOD of Anatomy , Saveetha Medical College for their encouragement and support. I Thank Dr. Gopi , Saveetha Medical College, Chennai for rendering his help in statistical work,.

Note: This study is a partial work of my Ph.D research, titled "An experimental anatomical study on the effectiveness of punarnava (Boerhaevia diffusa) on gentamycin induced renal failure in albino rat and to estimate the drug induced damage and revival of renal tissue". Part of this work has been published in iosrjdms journals with gentamycin nephrotoxicity.

\section{References}

[1] Nephrol Dial Transplant. 1994;9 Suppl 4:135-40 Singh RH, Udupa KN. Studies on the Indianindigenous drug Punarnava (Boerhaavia diffusa L.) Part I, Identification and pharmacological studies. J Res Ind Med 1972; 7: 1-12. 25

[2] Gaitonde BB, H. Kulkarn, Nabar SD. Diuretic activity of punarnava (Boerhaavia diffusa). Bull. Haffkine Inst. 1974; 2: $24-25$.

[3] Singh RH, Udupa KN. Studies on the Indianindigenous drug Punarnava (Boerhaavia diffusa L.) Part I, Identification and pharmacological studies. J Res Ind Med 1972; 7: 1-12. 25.

[4] Pareta SK, Patra KC, Mazumder PM, Sasmal D. Boerhaavia diffusa linn aqueous extract as curative agent in ethylene glycol induced urolithiasis. Pharmacologyonline 2011;3: 112-120.)

[5] Mishra J, Singh R. The effect of indigenous drug Boerhaavia diffusa on kidney regeneration. IndJ Pharmacol 1980; 12: 59-64. 24.

[6] Dvipriya S, Shyamaladevim CS. Protective effect of quercetin in cisplatin induced cell injury in the rat kidney. Indian J. Pharmacol. 1999; 31: 422-423.)

[7] Ali,B.H.; Al-Qarawi, A.A.; Haroun,E.M. and Mousa, H.M.(2003): The effect of treatment with gum arabic on gentamicin nephrotoxicity in rats Ren Fail., 25(1):15-20.

[8] Goto, A.M. (2004): "The role of lipid coronary heart disease" Kalamazoo, M. I. Upjhion Company

[9] Heibashy, M.I.A.; El-Nahla, A.M.; Ibrahim, A.I. and Saleh, Sh.Y.A. (2009): Comparative study between dimethyl sulfoxide (DMSO), allopurinol and urate oxidase administration in nephrotoxic rats induced with gentamicin. 43rd Annual Veterinary Medical Symposium, College of Veterinary Medicine Nursing and Allied Health, Tuskegee University, Alabama, USA

[10] Heibashy, M. I. A. and Abdel Moneim, A. E. (1999): Kidney and liver function tests after late Dimethyl sulfoxide (DMSO) administration in rats with gentamicin induced acute renal failure. J. Egypt. Ger. Soc. Zool., 30(A): $35-48$.

[11] K.Vijay Kumar, M.U.R. Naidu, Anwar A. Shifow, *K.S. Ratnakar Probucol protects against gentamicin-induced nephrotoxicity in ratsindian journal of pharmacology 2000; 32: 108-113

[12] Shirwaikar A, Malini S, Kumari SCProtective effect of Pongamia pinnata flowers against cisplatin and gentamicin induced nephrotoxicity in ratsIndian J Exp Biol. 2003 Jan;41(1):58-62.

[13] Surendra K. Pareta, Kartik C.Patra, Ranjeet Harwansh, Manoj Kumar, Kedar Prasad Protective Effects of Boerhaavia Diffusa Against Acetaminophen-Induced "Nephrotoxicity in Rats Pharmacologyonline 2: 698-706 (2011)

[14] Indhumathi T, K.Shilpa, S.Mohandass Evaluation of Nephroprotective role of Boerhaavia diffusa leaves against mercuric chloride induced toxicity in experimental rats.Received on: 11-02-2011; Revised on: 16-03-2011; Accepted on:21-04-2011T.Indhumathi et al. / Journal of Pharmacy Research 2011,4(6),1848-1850)

[15] Rawat, A.K.S., Mehrotra, S., Tripathi, S.K., and Shama, U. (1997). Hepatoprotective activityin punarnava - a popular Indian ethnomedicine. Journal of Ethnopharmacology 56(1):61-68. 